\title{
Martial Art as Sport and as Real Life Fight
}

\author{
Edvard Sefer* \\ Independent Consultant, Founder (Soke) of the Monku Jutsu Art Style of Self Defense, Europe
}

Submission: March 12, 2018; Published: March20, 2018

*Corresponding author: Edvard Sefer, Independent Consultant, Founder (Soke) of the MonkuJutsu Art Style of Self Defense, Europe, Tel: 0038673847180; Email: sefer@siol.net

Abstract

The aim of this text is to explain difference between sport and real life fight. The materials and methods used for this research include a study of literature, old Chinese drawings, practical experience with Monku Jutsu, acupressure point fighting, history, Kata forms, anatomy, and body kinetics, as well as Chinese and modern philosophy.

\section{Introduction}

To understand any knowledge, you must know the knowledge history. Thus Confucius wrote, "Study the past, if you would divine the future," and Johan Wolfgang von Goethe (1749-1823), the famous German writer, poet, scientist, and philosopher, said that the "history of a science is that science alone."

It is commonly accepted that Martial art we know today started with Bodidharma who was a Buddhist monk lived during the fifth or sixth century AD. The fact is that Bodhidharma was a very intelligent and well-educated man who traveled a lot in his life. At that time, most people did not travel more than two days by foot from their homes in all of their lives. As the philosopher Certeau explains, it was important to Bodhidharma that he did not live permanently in some monastery where he would be under the pressure of higher priests who wanted to explain the "truth" to him. He was free, and his mind was free, so that he could observe and come to his own conclusions.

On his travels, he observed animals what they do and how they live and out of his observations, he as a monk develops martial art of self-defense, because monks are not aggressors and violent persons. Self-defense is not only defending oneself through blocking, kicking, and striking attacks. Defense through blocking cannot continue until the attacker gets tired and stops attacking. Self-defense is from the first step a form of protecting oneself from an attacker and in the correct moment turning one's defense to offense, finishing by seriously harming or killing the attacker. As Sun Tzu said, "In ancient times the experienced warrior first assured his own invulnerability and then waited for his enemy's vulnerability." I followed Bodidharma observation and my first observation was that male animals fight their own kind (imagine bulls, monkeys, or cats) to show who is stronger; there is pushing and punching like in sports, but normally neither participant dies and the stronger male wins the right to inseminate a female. On other side when animals are hunting food, they catch their prey; they never let a trapped animal escape only to start the chase again. When they catch their prey, they hold it tightly (imagine a tiger, snake, or hawk) and try to immediately break or harm its leg to prevent it from escaping; then, it breaks its neck or presses on its throat to choke it.

Like all other animals, humans have fought amongst each other from the very beginning for prey, females, and, later, for land and other valuables. From the very beginning, there were two kinds of fights: one to show off in front of females so that they could choose the best inseminator, and another to steal something valuable from another person. The first type of fight generally do not end with the death of the loser; in the second type of fight over the valuable object, the participants would try to kill one another in order to finalize the new acquisition forever. Today, we call the first type of fight a sport fight, and the second a street fight or war.

Sport fights are mostly between opponents of a similar size and power capability. In nature, smaller does not attack bigger, and if bigger attacks smaller, the smaller will try to survive by running away; it will only accept a fight if there is no way to escape.

It is very important to understand that fighting sports are games, and games have rules, limited place, Agon, and Ludus as described by Caillois, Fink and Huizinga. Agon is the rule of competitor equality and Ludus includes the rules that make things unnecessarily more difficult and, at same time, prolong the sporting fight so that those who paid for entrance tickets can satisfy their need for violence. I find the most significant difference between sports and real life situations to be that in 
sporting games you can always give up and surrender to protect yourself from injury and your competitor will respect that; in real life, the winning attacker will not respect your wish.

Real fight or war is opposite to that because everybody wants to finish the fight as soon as possible to save human and material resources. Sun Tzu (544-496 BC) in his book The Art of War explains it very clearly with following wisdoms:

a) Haste is madness, but I have never seen a smart delay b) In war, victory must be fast. If victory is slow, men get tired

c) In war price, the victory not prolonged warfare.

\section{Conclusion}

Martial art sports are game where people do not kill each other and real life Martial art is meant for killing.

\section{Your next submission with Juniper Publishers} will reach you the below assets

- Quality Editorial service

- Swift Peer Review

- Reprints availability

- E-prints Service

- Manuscript Podcast for convenient understanding

- Global attainment for your research

- Manuscript accessibility in different formats

( Pdf, E-pub, Full Text, Audio)

- Unceasing customer service

Track the below URL for one-step submission https://juniperpublishers.com/online-submission.php 